\title{
PENGAJARAN REFLEKTIF MAHASISWA CALON GURU PENDIDIKAN MATEMATIKA
}

\author{
Hedi Budiman \\ Pendidikan Matematika, FKIP, Universitas Suryakancana \\ hedi@unsur.ac.id
}

\begin{abstract}
ABSTRAK
Program Praktek Lapangan (PPL) merupakan sarana untuk menerapkan kemampuan yang sudah diperoleh mahasiswa calon guru secara teoritis di bangku kuliah. Selain kemampuan dalam penguasaan materi, mahasiswa calon guru juga dituntut dalam kemampuan berkomunikasi dan berinteraksi yang baik ketika mengajar siswa di kelas. Kegiatan PPL ini merupakan pelatihan untuk menjadi guru profesional, karena di dalamnya terkait sejumlah kemampuan pengajar yang professional. Idealisme yang diharapkan terhadap mahasiswa calon guru ini perlu didampingi dengan pengontrolan pada pelaksanaan dan pengkajian setelah pelaksanaannya. Salah satu upaya yang dilakukan terhadap proses pengajaran yang sudah dilakukan yaitu dengan observasi dan refleksi. Pengajaran reflektif seorang calon guru atau guru professional, berkaitan dengan kemampuan dan disposisi berpikir reflektif. Hasil penelitian menunjukkan bahwa para mahasiswa calon guru matematika ini pada umumnya sudah menunjukkan kemampuan reflektif dalam hal openmindness (keterbukaan), responsibility (tanggungjawab), wholeheartedness (kesungguhan dalam bertindak) untuk meningkatkan pengajaran di kelas. Kemampuan ini sangat bermanfaat dan perlu ditingkatkan ketika sudah menjadi guru kelas.
\end{abstract}

Katakunci: Openmindness, Responsibility, Wholeheartedness, Reflektif

\section{PENDAHULUAN}

Mengembangkan kemampuan berpikir matematik menjadi fokus para pendidik matematika di kelas. Salah satu harapan yang ingin dicapai oleh mahasiswa adalah dimilikinya kemampuan berpikir matematis tingkat tinggi. Kemampuan ini sangat diperlukan mahasiswa calon guru, terkait dengan posisinya sebagai guru matematika ketika sudah menyelesaikan pendidikan sarjananya. Mahasiswa calon guru ini diharapkan menguasai materi matematika dan mampu mengajarkannya kepada siswa.

Berdasarkan aturan di Fakultas Keguruan dan Ilmu Pendidikan, mahasiswa calon guru yang sudah lulus sejumlah mata kuliah kelompok akademik dan pedagogik, diwajibkan melaksanakan Program Praktek Lapangan (PPL). Adanya PPL ini mendorong mahasiswa untuk melatih keterampilan mengajar di kelas, yang merupakan tahap awal karir dalam mengajar. Pelatihan mengajar ini juga dapat mengurangi tingkat stres calon guru dalam pengajaran di kelas. Proses pengajaran yang terus menerus dapat membentuk pola pengajaran yang sesuai standar dan mampu menerapkan strategi pengajaran yang sesuai. Idealisme yang 
diharapkan terhadap mahasiswa calon guru ini perlu didampingi dengan pengontrolan pada pelaksanaan dan pengkajian setelah pelaksanaann PPL. Salah satu upaya yang dilakukan yaitu melalui pengamatan dan perenungan sendiri terhadap proses pengajaran yang sudah dilakukan dengan melakukan observasi dan refleksi. Pendekatan dalam mengajar ini disebut sebagai pengajaran reflektif. Pengajaran reflektif seorang calon guru atau guru professional, berkaitan dengan kemampuan dan disposisi berpikir reflektif. Berpikir reflektif sangat penting untuk perbaikan dalam pelaksanaan pengajaran. Menurut Dohn (2011), kemampuan reflektif ini semakin dilihat sebagai faktor penting dalam pengelolaan pembelajaran, dan peningkatan kompetensi. Reflektif melibatkan banyak keterampilan yang kompleks. Keterlibatan siswa dalam lingkungan belajar, mendorong guru untuk berpikir reflektif.

Zeichner \& Liston (1996) menyatakan bahwa upaya pemahaman dan peningkatan pengajaran seorang guru, harus dimulai dari refleksi atas pengalaman sendiri. Bright (1996) menyatakan bahwa berpikir reflektif adalah proses yang mendasari semua bentuk kompetensi pengajaran profesional yang tinggi. Berpikir reflektif dapat menjadi bermakna jika pemahaman yang diperoleh berasal dari refleksi yang digunakan untuk mempengaruhi perubahan diri (Adam, 2002). Individu harus kritis mengkaji apa yang sudah dilakukannya. Jika konsep refleksi bukan tidak dipergunakan untuk melakukan pengkajian, maka akan terjadi kesalahan persepsi (Ash dan Clayton, 2004). Konsep guru reflektif merupakan karakteristik dari individu yang berpikir profesional dan melakukan perubahan di kelas (Pereira, 2011).

Dewey (1991) menjelaskan tentang pendidikan guru, dan pendekatan reflektif sebagai alternatif model pada pendidikan guru. Dewey mengkritik tentang pendidikan guru yang didominasi oleh orientasi teknis, di mana calon guru dibimbing untuk menguasai keterampilan teknis, dan bagaimana mengajarnya, tanpa mempertimbangkan prinsip-prinsip atau filsafat pengajarannya. Diagnosis Dewey dalam pendidikan guru masih terjadi di saat sekarang. Ada kekhawatiran bahwa guru dilatih sebagai teknisi terampil yang terbatas pada perilaku dan kebiasaan dalam tindakannya daripada kemampuan berpikirnya yang cermat (Valli, 1997). Kelemahan mendasar dalam persiapan guru sering dikaitkan dengan pendekatan tradisional untuk pendidikan calon guru.

Hasil penelitian Korthagen (2001) terhadap mahasiswa calon guru yang melakukan praktek mengajar di kelas, menunjukkan kekurang mampuan dalam mengajar sesuai 
pengetahuan yang dimiliki sebelumnya atau terjadinya kesenjangan antara teori dan praktek. Korthagen menjelaskan bahwa para mahasiswa calon guru tersebut menganggap teori tidak sesuai dengan praktek pelaksanaannya, dan mahasiswa yang berusaha untuk menerapkan teori yang diperolehnya mudah kehilangan motivasi dalam mengajar. Akibatnya, para mahasiswa calon guru tersebut setelah menyelesaikan program paraktek lapangan (PPL) akan menghadapi tantangan berat ketika menjadi guru setelah menyelesaikan pendidikan sarjananya. Faktor lain yang memiliki pengaruh negatif pada pengalaman di lapangan adalah para mahasiswa ini tidak mau mengambil risiko dengan ide-ide inovatif selama praktek mengajarnya, karena kekhawatiran tidak tercapainya target yang berdampak pada nilai praktek yang diperolehnya (Bullough et al., 2003).

Selain itu Korthagen (2001) menyuarakan keprihatinan terhadap pendidikan guru. Dia menyatakan bahwa dalam kebanyakan kasus, pendidikan guru umumnya menjadi terlalu teoritis, yang dapat menciptakan kondisi ketidakseimbangan dalam pendidikan guru seharusnya. Pendidikan guru harus di dorong pada strategi penerapan konstruktivis, yaitu para mahasiswa calon guru ini dapat mengembangkan pengetahuan sendiri melalui proses refleksi yang mendorong untuk selalu memperbaiki kekurangan yang dilakukan dalam praktek mengajar. Dalam hal ini, penekanannya pada penguasaan keterampilan dan kompetensi yang berorientasi pada observasi, interaksi antara siswa, dan pengembangan keterampilan pengajaran reflektif. Hal ini sesuai dengan pendapat Dewey yang menganggap penting untuk melakukan observasi pada prinsip-prinsip etika, empiris, teoritis, dan praktis dalam proses pengajaran (LaBoskey, 1992).

Seorang guru berperan penting dalam mendorong berpikir matematik siswa. Guru juga memiliki tanggung jawab untuk mendorong keputusan siswa untuk lepas dari keraguan pada pelaksanaan pembelajaran (Dinkelman, 2000). Sementara Takona (2002) lebih jauh menyatakan bahwa guru perlu mengevaluasi pencapaian siswa dalam kemampuan berpikirnya, termasuk tanggung jawabnya untuk melatih kemampuan melakukan refleksi di kalangan siswa sehingga dapat bekerja efektif dalam kehidupan di masa depannya. Proses ini akan semaikn mematangkan kemampuan reflektif kritis dari guru dalam pengajarannya

Realitas beberapa hasil penelitian yang sudah dilakukan ini mendorong peneliti untuk melakukan pengjkajian tentang program praktek pengajaran di lapangan (PPL) mahasiswa 
calon guru pendidikan matematika setelah melakukan praktek lapangan.

\section{METODOLOGI PENELITIAN}

Penelitian ini merupakan penelitian deskriptif kuantitatif dengan metode korelasional untuk melihat pengaruh Openmindedness (keterbukaan), Responsibility (tanggungjawab) dan Wholeheartedness (kesungguhan dalam bertindak) terhadap pengajaran reflektif mahasiswa. Penelitian korelasi atau korelasional adalah suatu penelitian untuk mengetahui hubungan dan tingkat hubungan antara dua variabel atau lebih tanpa ada upaya untuk mempengaruhi variabel tersebut sehingga tidak terdapat manipulasi variabel (Fraenkel dan Wallen, 2012). Penelitian korelasi adalah penelitian untuk mengetahui sejauh mana hubungan variasi-variasi pada satu atau lebih faktor lain berdasarkan koefisien korelasi. Desain penelitiannya dapat digambarkan sebagai berikut;

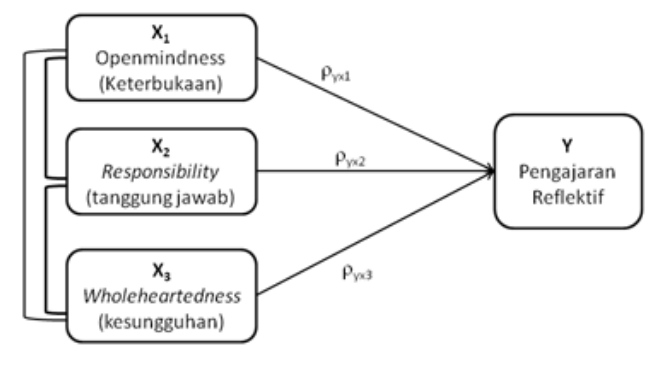

\section{Gambar 1 Paradigma Penelitian}

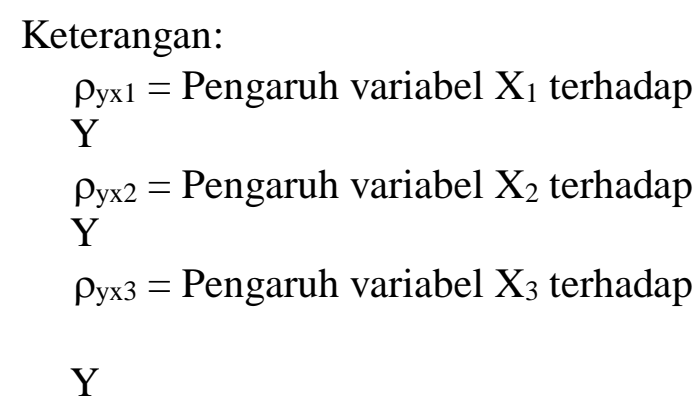

Keterangan:

$\rho_{\mathrm{yx} 1}=$ Pengaruh variabel $X_{1}$ terhadap

$\rho_{\mathrm{yx} 2}=$ Pengaruh variabel $\mathrm{X}_{2}$ terhadap $\mathrm{Y}$

\section{$\mathrm{Y}$}

Populasi pada penelitian ini adalah seluruh mahasiswa pendidikan matematika yang sudah melaksanakan Program Praktek Lapangan (PPL). Teknik penentuan sampel dalam penelitian ini dengan menggunakan Stratified Random Sampling yaitu cara pengambilan sampel dari anggota populasi secara acak dan berstrata. Sampel dalam penelitian ini adalah 80 mahasiswa semester VII pendidikan matematika.. Variabel pada penelitian ini terdiri dari variable bebas dan variable terikat. Variabel bebas atau variabel independen mempengaruhi variable terikat atau variable dependen. Yang menjadi variabel bebas adalah Openmindedness (keterbukaan) yang dinotasikan dengan variable $\mathrm{X}_{1}$, Responsibility (tanggung jawab) yang dinotasikan dengan variabel $\mathrm{X}_{2}$ dan Wholeheartedness (kesungguhan dalam bertindak) yang dinotasikan dengan variabel $X_{3}$. Sedangkan variabel terikat adalah Pengajaran reflektif mahasiswa yang dinotasikan dengan variable $\mathrm{Y}$. 
Instrumen dalam penelitian menggunakan kuesioner dengan skala Likert. Fraenkel dan Wellen (2012), skala Likert merupakan instrumen di mana seorang individu merespon serangkaian pernyataan yang menunjukkan tingkat kesepakatan. Pada penelitian ini digunakan skala Likert dengan 4 pilihan pernyataan dengan penentuan skor, yaitu (4) untuk jawaban "sangat sering"; (3) untuk jawaban "sering"; (2) untuk jawaban "jarang"; dan (1) untuk jawaban "tidak pernah", untuk pernyataan positif. Dan pada pernyataan negatif digunakan penskoran sebaliknya. Tidak digunakannya skor untuk jawaban "kadang-kadang" karena dikhawatirkan siswa cenderung memilih jawaban kadang-kadang dalam setiap menjawan pernyataan.

Data yang dikumpulkan terdiri dari data primer dan data sekunder. Data primer adalah data yang diperoleh langsung dari objek penelitian sesuai dengan ruang lingkup dan kebutuhannya, sedangkan data sekunder adalah data yang diperoleh secara tidak langsung dari objek yang diteliti, maupun dari dokumen dan catatan lainnya yang menunjang dalam pembahasan penelitian. Pengumpulan data primer dilakukan melalui kuesioner, wawancara, hasil tes dan observasi. Sedangkan pengumpulan data sekunder dilakukan melalui studi literatur yaitu penelitian dengan jalan mempelajari buku-buku dan dokumen yang ada kaitannya dengan materi penelitian.

\section{HASIL DAN PEMBAHASAN}

\section{Hipotesis 1 : Pengaruh Openmindedness (keterbukaan) terhadap Pengajaran Reflektif}

Uji linearitas Openmindedness (keterbukaan) terhadap pengajaran reflektif menunjukan sig. $=0,098>0,05$. Dan berdasarkan tabel, untuk df $(13,62)$ diperoleh $F_{\text {tabel }} 1,87$ yang lebih besar dari $F_{\text {hitung }}=1,637$. Hal ini menunjukkan bahwa terdapat hubungan linear secara signifikan antara variabel Openmindedness (X1) dengan variable Pengajaran Reflektif (Y). Hasil korelasi parsial antara openmindedness dengan variable pengajaran reflektif dengan kontrol responsibility sebesar 0,406 yang berkategori sedang dan kontrol Wholeheartedness sebesar 0,361 yang berkategori rendah.

\section{Hipotesis 2 : Pengaruh Responsibility terhadap Pengajaran Reflektif}

Uji linearitas responsibility dan pengajaran reflektif belajar menunjukan sig. $=0,834>$ 
0,05. Dan berdasarkan tabel, untuk df $(13,63)$ diperoleh $F_{\text {tabel }} 1,87$ yang lebih besar dari $F_{\text {hitung }}$ $=0,614$. Hal ini menunjukkan bahwa terdapat hubungan linear secara signifikan antara variabel responsibility (X2) dengan variable pengajaran reflektif (Y). Hasil korelasi parsial antara responsibility dengan variable pengajaran reflektif dengan kontrol openmindness sebesar 0,407 yang berkategori sedang dan kontrol Wholeheartedness sebesar 0,466 yang berkategori sedang

\section{Hipotesis 3 : Pengaruh Wholeheartedness terhadap Pengajaran Reflektif}

Uji linearitas wholeheartedness terhadap pengajaran reflektif menunjukan sig. $=0,172$ $>0,05$. Dan berdasarkan tabel, untuk df $(14,64)$ diperoleh $F_{\text {tabel }} 1,85$ yang lebih besar dari $F_{\text {hitung }}=1,415$. Hal ini menunjukkan bahwa terdapat hubungan linear secara signifikan antara variabel wholeheartedness (X3) dengan variable pengajaran reflektif (Y). Hasil korelasi parsial antara wholeheartedness dengan variable pengajaran reflektif dengan kontrol openmindness sebesar 0,550 yang berkategori sedang dan kontrol responsibility sebesar 0,527 yang berkategori sedang

\section{Hipotesis 4 : Pengaruh Openmindness, Responsibility dan Wholeheartedness terhadap Pengajaran Reflektif}

Dari hasil uji F, didapat $\mathrm{F}_{\text {hitung }}$ yaitu 24,467 ( $\left.\mathrm{p}=0,000\right)$, signifikan. Dari tabel distribusi

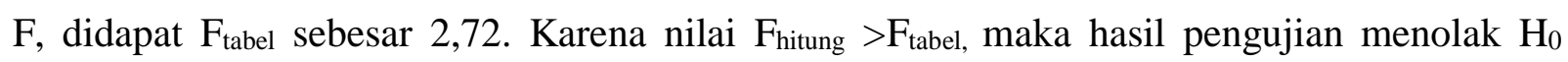
artinya openmindness, responsibility dan wholeheartedness berpengaruh terhadap pengajaran reflektif. Hal ini berarti semakin tinggi openmindness, responsibility dan wholeheartedness maka semakin tinggi kemampuan pengajaran reflektif mahasiswa calon guru. Besarnya angka koefisien korelasi pengaruh openmindness, responsibility dan wholeheartedness secara bersama-sama terhadap pengajaran reflektif mahasiswa calon guru adalah 0,701. Hal ini menunjukkan bahwa pengaruh openmindness, responsibility dan wholeheartedness terhadap pengajaran reflektif mahasiswa calon guru termasuk kedalam kategori tinggi.

Besarnya nilai koefesien determinasi (R Square) yaitu sebesar 0,491 artinya sebesar 49,1\% variabel pengajaran reflektif (Y) dipengaruhi secara bersama-sama oleh variabel openmindness $\left(\mathrm{X}_{1}\right)$, responsibility $\left(\mathrm{X}_{2}\right)$, dan wholeheartedness $\left(\mathrm{X}_{3}\right)$, sedangkan sisanya sebesar 
50,9 \% dipengaruhi oleh faktor lain. Persamaan regresi ganda dari pengaruh openmindness, responsibility, dan wholeheartedness terhadap pengajaran reflektif adalah $\mathrm{Y}=7,094+$ $0,103 \mathrm{X}_{1}+0,257 \mathrm{X}_{2}+0,476 \mathrm{X}_{3}$, dari persamaan itu menunjukkan pengajaran reflektif siswa akan naik, jika ada peningkatan pada openmindness, responsibility dan wholeheartedness.

Penelitian dilakukan untuk dapat mengidentifikasi openmindness (keterbukaan), responsibility (tanggung jawab) dan wholeheartedness (kesungguhan dalam bertindak) terhadap pengajaran reflektif mahasiswa calon guru. Pembelajaran matematika yang diajarkan guru di kelas berpengaruh pada respon siswa terhadap pelajaran matematika dalam jangka panjang. Para mahasiswa calon guru pada saat praktek mengajar (Program Praktek Lapangan atau PPL dan melakukan penelitian skripsi, merupakan langkah awal dalam menerapkan teori yang diperoleh di kampus. Pengajaran reflektif ini penting bagi guru kelas untuk meningkatkan kualitas pengajaran kepada para siswa. Dengan memulai membangun kemampuan reflektif dalam penajaran pada calon guru ini, diharapkan pada saat menjadi guru kelas, dapat tetap memperhatikan peningkatan pengajaran, supaya apa yang disampaikan benar-benar dapat dipahami para siswa dan dapat meningkatkan kemampuan matematikanya.

Dari persamaan regresi menunjukkan openmindness (keterbukaan), responsibility (tanggung jawab) dan wholeheartedness (kesungguhan dalam bertindak) berkorelasi positif dengan pengajaran reflektif. Dengan meningkatnya openmindness (keterbukaan), responsibility (tanggung jawab) dan wholeheartedness (kesungguhan dalam bertindak) maka pengajaran reflektif mahasiswa calon guru jadi meningkat. Besarnya pengaruh openmindness (keterbukaan) terhadap pengajaran reflektif sebesar 22,6\%. Dan 22,6\% tinggi rendahnya pengajaran reflektif mahasiswa calon guru dipengaruhi oleh openmindness (keterbukaan), sisanya sebesar 77,4\% dipengaruhi variable lain diluar openmindness (keterbukaan) yang tidak dijelaskan model. Tinggi rendahnya pengajaran reflektif mahasiswa calon guru dipengaruhi oleh responsibility (tanggung jawab) sebesar 28,7 \% dan sisanya 71,3\% dipengaruhi variabel lain diluar responsibility (tanggung jawab). Sedangkan tinggi rendahnya pengajaran reflektif mahasiswa calon guru dipengaruhi oleh wholeheartedness (kesungguhan dalam bertindak) sebesar 44,6\% dan sisanya 55,4\% dipengaruhi variabel lain diluar wholeheartedness (kesungguhan dalam bertindak). Dan secara bersama-sama sebesar 49,1\% tinggi rendahnya 
pengajaran reflektif mahasiswa calon guru dipengaruhi oleh openmindness (keterbukaan), responsibility (tanggung jawab) dan wholeheartedness (kesungguhan dalam bertindak), sedangkan sisanya 50,9\% merupakan pengaruh variabel lain diluar openmindness (keterbukaan), responsibility (tanggung jawab) dan wholeheartedness (kesungguhan dalam bertindak) yang tidak dijelaskan model.

Tabel 1 Respon Mahasiswa Calon Guru terhadap Openmindness

\begin{tabular}{lcccccccccc}
\hline & \multicolumn{10}{c}{ Jumlah Respon terhadap Pernyataan (\%) } \\
\cline { 2 - 12 } Kategori & 1 & 2 & 3 & 4 & 5 & 6 & 7 & 8 & 9 & 10 \\
& + & - & + & - & + & - & + & + & + & - \\
\hline Sangat Sering & 25.0 & 3.8 & 45.0 & 1.3 & 16.3 & 0.0 & 12.5 & 26.3 & 30.0 & 0.0 \\
\hline Sering & 68.8 & 16.3 & 51.3 & 11.3 & 57.5 & 11.3 & 35.0 & 60.0 & 62.5 & 10.0 \\
\hline Jarang & 6.3 & 51.3 & 3.8 & 62.5 & 18.8 & 38.8 & 40.0 & 12.5 & 6.3 & 55.0 \\
\hline Tidak pernah & 0.0 & 28.8 & 0.0 & 25.0 & 7.5 & 50.0 & 12.5 & 1.3 & 1.3 & 35.0 \\
\hline
\end{tabular}

Dalam openmindness (keterbukaan), para mahasiswa calon guru ini pada umumnya memperhatikan siswa saat mengajar, hal ini dimungkinkan karena merupakan pengalaman pertama berdiri didepan kelas dihadapan para siswa dalam menjelaskan materi pelajaran. Sekitar 79\% mahasiswa merasa yakin bisa mengajar di kelas, sehingga terlihat kesungguhan mahasiswa dalam menjalankan tugas mengajarnya. Mahasiswa cenderung berpikir bagaimana caranya supaya para siswa yang diajarnya bisa memahami pelajaran dan merasa mampu dalam menyelesaikan soal-soal yang diberikan, dan sebanyak $20 \%$ mahasiswa tidak memperhatikan hal itu.

Mahasiswa calon guru juga umumnya menunjukkan sikap positifnya ketika mengajar, karena sikap guru dalam mengajar matematika juga menjadi salah satu penentu pemahaman siswa dalam pelajaran matematika. Mahasiswa calon guru sudah mulai mengamati pengaruh pengajaran yang diberikan di kelas terhadap kemampuan siswa yang rendah dan sedang, yang umumnya sulit memahami materi dengan cepat. Sekitar 26\% nahasiswa calon guru tidak terlalu mengamati kemampuan siswa di kelas, dan cenderung mensamaratakan kemampuan siswanya.

Responsibility (tanggungjawab) mahasiswa calon guru dalam mengajar terlihat dalam mencermati sikap yang ditunjukkan di kelas, bagaimana pengaruh pengajaran terhadap pemahaman siswa. Sikap hati-hati ditunjukkan oleh $89 \%$ mahasiswa saat mengajar di kelas, 
karena mengkhawatirkan kesalahan dalam menjelaskan materi di kelas yang akan berpengaruh pada pemahaman siswa. Hal ini diperkuat dari upaya refleksi diri ditunjukkan dengan mulai menyadari kemungkinan adanya kesalahan dalam proses pengajaran, walaupun $30 \%$ mahasiswa tidak memikirkan kesalahan tersebut. Keinginan $88 \%$ mahasiswa calon guru untuk menunjukkan sesuatu yang baru dalam mengajar di kelas memperlihatkan pengaruh pembelajaran di kampus, sudah cukup membekali dalam melaksanakan praktek mengajar yang menarik siswa. Selain itu peningkatan kemampuan berdasarkan kemampuan siswa, menjadi perhatian sebagian besar mahasiswa, dan hanya 6\% kurang memperhatikan kemampuan siswa.

Tabel 2 Respon Mahasiswa Calon Guru terhadap Responsibility

\begin{tabular}{lcccccccccc}
\hline \multirow{2}{*}{ Kategori } & 11 & 12 & 13 & 14 & 15 & 16 & 17 & 18 & 19 & 20 \\
& - & + & + & + & + & + & + & + & + & + \\
\hline Sangat Sering & 0.0 & 33.8 & 17.5 & 22.5 & 3.8 & 11.3 & 10.0 & 37.5 & 17.5 & 20.0 \\
\hline Sering & 6.3 & 53.8 & 52.5 & 61.3 & 7.5 & 61.3 & 56.3 & 53.8 & 50.0 & 61.3 \\
\hline Jarang & 26.3 & 11.3 & 26.3 & 16.3 & 33.8 & 21.3 & 27.5 & 8.8 & 30.0 & 17.5 \\
\hline Tidak pernah & 67.5 & 1.3 & 3.8 & 0.0 & 55.0 & 6.3 & 6.3 & 0.0 & 2.5 & 1.3 \\
\hline
\end{tabular}

Respon mahasiswa dalam wholeheartedness (kesungguhan dalam bertindak), ditunjukkan dengan banyaknya pertimbangan yang dipikirkan mahasiswa calon guru saat mengajar. Pertimbangan terhadap strategi mengajar, pengontrolan sikap siswa di kelas, kecemasan siswa, interaksi sosial, kepercayaan diri siswa, kemandirian belajar, dan keberlanjutan di tingkat sekolah berikutnya. Para calon guru berpikir utuk menerapkan strategi mengajar alternatif untuk mendorong siswa agar lebih memahami materi, dan $12 \%$ mahasiswa tidak memikirkan penerapan strategi yang terbaik. Pada umumnya mahasiswa (72 \%) memiliki perhatian terhadap siswa dengan mengontrol sikap siswa selama proses pembelajaran. Perhatian para mahasiswa calon guru dalam hal perasaan cemas dalam diri siswa saat mempelajari matematika cukup baik, meskipun 34\% mahasiswa belum mencermati masalah kecemasan ini.

Para calon guru $(81 \%)$ juga sudah berlatih memperhatikan interaksi sosial antara siswa yang dapat membantu pemahaman siswa dalam kelompok. Karena salah satu ketidak pahaman siswa dipengaruhi oleh metode pengajaran matematika yang diberikan guru. Interaksi sosial ini juga bisa berpengaruh pada kepercayaan disi siswa dalam menyelesaikan soal-soal yang 
diberikan. Sebanyak 84\% mahasiswa memperhatikan masalah kepercayaan diri pada siswa ini. Harapannya, dengan kepercayaan diri siswa ini bisa mempengaruhi kemandirian belajarnya, yang akan bermanfaat pada masa depan siswa berikutnya. Perhatian ini sudah muncul pada $86 \%$ mahasiswa calon guru.

Tabel 3 Respon Mahasiswa Calon Guru terhadap Wholeheartedness

\begin{tabular}{lrrrrrrrrrrr}
\hline \multirow{2}{*}{ Kategori } & \multicolumn{10}{c}{ Jumlah Respon terhadap Pernyataan $(\%)$} \\
\cline { 2 - 13 } & 21 & 22 & 23 & 24 & 25 & 26 & 27 & 28 & 29 & 30 \\
& + & - & \multicolumn{1}{c}{+} & - & + & + & + & + & + & - \\
\hline Sangat Sering & 47.5 & 0.0 & 21.3 & 63.8 & 23.8 & 26.3 & 53.8 & 26.3 & 16.3 & 1.3 \\
\hline Sering & 43.8 & 2.5 & 65.0 & 22.5 & 55.0 & 57.5 & 40.0 & 57.5 & 66.3 & 12.5 \\
\hline Jarang & 8.8 & 28.8 & 12.5 & 10.0 & 20.0 & 15.0 & 5.0 & 15.0 & 16.3 & 32.5 \\
\hline Tidak pernah & 0.0 & 68.8 & 1.3 & 3.8 & 1.3 & 1.3 & 1.3 & 1.3 & 1.3 & 53.8 \\
\hline
\end{tabular}

Perhatian pada kemandirian ini penting terutama pada siswa SMP, karena menurut Budiman (2014), peranan guru dalam mengajar matematika di kelas sejak di sekolah memperlihatkan pengaruh yang cukup signifikan pada sebagian besar siswa yang merespon negatif pada pelajaran matematika. Kontribusi sikap negatif siswa ini diperkuat dengan problem individu siswa yang kurang gigih dalam usaha untuk memahami pelajaran. Akumulasi perasaan tertekan dalam setiap mengikuti pelajaran matematika di kelas saat di SMP akan tambah memperkuat rendahnya kemandirian belajar siswa terhadap pelajaran matematika.

Kemampuan refleksi pada guru umumnya sudah muncul pada sebagian mahasiswa calon guru dalam hal mengajar, berinteraksi dengan siswa, mengamati proses penyerapan materi oleh siswa, pencapaian nilai akhir dan penggunaan pendekatan pembelajaran kelompok. Coyle (2002) menyatakan pengajaran reflektif dapat mendorong guru untuk melakukan pendekatan yang kreatif dan inovatif untuk mengatasi masalah di kelas dan sekolah, dan ini bisa terwujud dalam meningkatkan kesempatan belajar bagi siswa. 
Jurnal PRISMA Universitas Suryakancana

Tabel 4 Respon Mahasiswa Calon Guru terhadap Pengajaran Reflektif

\begin{tabular}{lcccccccccc}
\hline \multirow{2}{*}{ Kategori } & \multicolumn{10}{c}{ Jumlah Respon terhadap Pernyataan (\%) } \\
\cline { 2 - 12 } & 31 & 32 & 33 & 34 & 35 & 36 & 37 & 38 & 39 & 40 \\
& + & + & + & + & + & + & + & + & \multicolumn{1}{c}{+} & + \\
\hline Sangat Sering & 1.3 & 2.5 & 25.0 & 30.0 & 31.3 & 2.5 & 31.3 & 2.5 & 12.5 & 51.3 \\
\hline Sering & 5.0 & 11.3 & 55.0 & 60.0 & 60.0 & 7.5 & 63.8 & 2.5 & 65.0 & 43.8 \\
\hline Jarang & 26.3 & 18.8 & 17.5 & 10.0 & 7.5 & 31.3 & 5.0 & 27.5 & 22.5 & 3.8 \\
\hline Tidak pernah & 67.5 & 67.5 & 2.5 & 0.0 & 1.3 & 58.8 & 0.0 & 67.5 & 0.0 & 1.3 \\
\hline
\end{tabular}

Kesadaran mahasiswa untuk melakukan refleksi pada saat mengajar ditunjukkan oleh 86\% mahasiswa. Sebanyak 90\% mahasiswa menganggap interkasi pengajar pada siswa di kelas sangat penting dalam meningkatkan kemampuan berpikir matematiknya. Pengamatan pada peningkatan berpikir matematik ini dilakukan oleh $90 \%$ mahasiswa calon guru. Begitu juga pada refleksi pengajar terhadap upaya peningkatan pencapaian siswa menjadi perhatian dari $91 \%$ mahasiswa calon guru. Perhatian pada pendekatan pembelajaran kelompok menjadi dilakukan oleh $87 \%$ mahasiswa, dengan harapan ada peningkatan pemahaman materi oleh siswa,sehingga hasilnya bisa sesuai dengan harapan di awal pembelajaran. Pendekatan kelompok ini bermanfaat untuk lebih mengamati siswa secara individu, mengamati kelebihan dan kekurangannya, sebagai langkah awal dalam proses pengajaran berikutnya.

\section{KESIMPULAN}

Berdasarkan hasil penelitian yang sudah dilakukan, dapat disimpulkan:

1. Hasil analisis regresi menunjukkan openmindness (keterbukaan) mahasiswa calon guru berpengaruh positif pada pengajaran reflektif dalam pelajaran matematika. Semakin tinggi tingkat openmindness (keterbukaan), maka semakin tinggi tingkat pengajaran reflektif mahasiswa calon guru.

2. Responsibility (tanggung jawab) mahasiswa calon guru berpengaruh positif pada pengajaran reflektif dalam pelajaran matematika. Semakin tinggi tingkat Responsibility, maka semakin tinggi tingkat pengajaran reflektif mahasiswa calon guru.

3. Wholeheartedness (kesungguhan dalam bertindak) mahasiswa calon guru berpengaruh positif pada pengajaran reflektif dalam pelajaran matematika. Semakin tinggi tingkat berpengaruh positif pada pengajaran reflektif dalam pelajaran matematika. Semakin tinggi 
Jurnal PRISMA Universitas Suryakancana

tingkat responsibility, maka semakin tinggi tingkat pengajaran reflektif mahasiswa calon guru.

4. Pengajaran reflektif mahasiswa calon guru termasuk pada kategori sedang. Hal ini dimungkinkan karena pengetahuan pengajaran reflektif pada pengajar di kelas, dapat menentukan keberhasilan siswa dalam memahami pelajaran yang diberikan dan meningkatkan kemampuan berpikirnya.

\section{REFERENSI}

Adam, A. (2002). Exploring the gender question in critical information systems. Journal of Information Technology, 17(2), 59-67.

Ash, S. L., \& Clayton, P. H. (2004). The articulated learning: An approach to guided reflection and assessment. Innovative Higher Education, 29(2), 137-154.

Bright, B. (1996). Reflecting on Reflective Practice. Studies in the Education of Adults. Vol.28. No. $2: 162-184$.

Budiman, H. (2014). Pengaruh Kecerdasan Emosional dan Kecemasan Matematika terhadap Kemandirian Belajar Siswa. FKIP UNSUR: Tidak diterbitkan.

Bullough, R., \& Pinnegar, S. (2001). Guidelines for quality in autobiographical forms of selfstudy research. Educational Researcher, 30(3), 13-21.

Dewey, J. (1991). How We Think. (Rev. ed.). Boston: D. C. Heath.

Dinkelman, T. (2000). An Inquiry Into The Development of Critical Reflection in Secondary Student Teachers. Teaching and Teacher Education, 16(2).

Dohn, N. B. (2011). On the epistemological presuppositions of reflective activities. Educational Theory, 61(6).

Fraenkel, J.R dan Wellen, N.E. (2012). How to Design and Evaluate Research in Education. New York: McGraw-Hill.

Korthagen, F. A. J. (2001) Linking Practice and Theory: The Pedagogy of Realistic Teacher Education. Mahawah, NJ: Lawrence Erlbaum Associates

Laboskey, V.K. (1994). Development of Reflective Practice: a study of preservice teachers. New York: Teachers College Press.

Pereira, F. (2011). In-service teacher education and scholar innovation: The semantics of action and reflection on action as a mediation device. Australian Journal of Teacher Education, 36(11).

Takona, J. P. (2002). Pre-service Teacher Portfolio Development. Lincoln, NE: Writers Club Press.

Valli, L. (1997). Listening to other voices: A description of teacher reflection in the United States. Peabody journal of Education, 72 (1), 67-88

Zeichner, K. M., \& Liston, D. P. (1996). Reflective Teaching: An Introduction. Mahwah, NJ: Lawrence Erlbaum Associates, Inc. 